\title{
Johann Jacob Wepfer Award 2007 of the European Stroke Conference to Prof. Charles Picton Warlow
}

Charles Picton Warlow was born in the 'vintage' year of 1943, under the zodiac sign, Libra, the Balance, and therefore he achieved a distinct maturation in the 1960s, blossoming fully in the late 1970s in Oxford and completing the final stage of perfection in Edinburgh from 1987 to date.

Reading a paper by Charles Picton Warlow, or listening to a presentation given by him, is always a pleasure. $\mathrm{He}$ is admirably capable of mixing paradoxes and facts, opinions and statistics, and exploiting the best catch from the waters he is navigating in. Very true because I have the feeling that Charles Picton Warlow is deeply fascinated by water, in all its different aspects.

In fact, when he moved to Aberdeen in 1971, he was not as much interested in stroke, which was the topic of only 1 paper out of 11 published between 1972 and 1975, as he was in skiing, a sport where he became highly skilful.

It is possible that his experiences with 'solid water' were a part of several factors that brought Charles Picton Warlow to his involvement with the firmness of what '... has become known as "evidence-based medicine" ...', as he recently wrote to me.

In Aberdeen he touched quickly upon several topics of neurology, from platelet adhesiveness to peripheral neuropathies, and more. I am particularly honoured to see that he was involved with radio-isotopes well ahead of their time, with a paper in the American Heart Journal in 1974 on the utilization of I-125 that followed a previous one in Lancet on I-131! His involvement with stroke, however, was already beginning, with a profound and supporting approach: the deep venous thrombosis of the legs after strokes, published in the British Medical Journal in the year 1976.

In 1974 Charles Picton Warlow moved back to London, and then Oxford, to train as a neurologist, and in less than 3 years he was appointed Clinical Reader in Neurology at the University of Oxford and Honorary Consultant Neurologist.

However, his leading figure in the field of cerebrovascular disorders was not yet established, and in fact his work was never quoted in the small but fundamental book written by John Marshall on The Transient Ischemic Attacks, with the 3rd edition published by Blackwell in 1976. The same absence of any reference to the work of Charles Picton Warlow is noticeable in the monograph Stroke - A Clinical Approach, by Lou Caplan and Robert Stein, published in 1986. This omission may be due to the Atlantic gap, which was far too wide for European authors to be recognized; a consideration supported at the European Stroke Conference in 1981, where Charles Picton Warlow was one of the founding fathers, and now this Wepfer Award to confirm and recognize European scientists' contributions to stroke research.

Charles Picton Warlow probably took his revenge in 2003 when he sent a recorded tape of his presentation for the prestigious Willis Lecture, to the American Stroke Conference in Phoenix.

\begin{tabular}{ll}
\hline KARGER & $\begin{array}{c}\text { (2) 2007 S. Karger AG, Basel } \\
1015-9770 / 07 / 0244-0387 \$ 23.50 / 0\end{array}$ \\
$\begin{array}{l}\text { Fax +41 61306 1234 } \\
\begin{array}{l}\text { E-Mail karger@karger.ch } \\
\text { www.karger.com }\end{array}\end{array}$ & $\begin{array}{l}\text { Accessible online at: } \\
\text { www.karger.com/ced }\end{array}$
\end{tabular}


The first papers on the Oxfordshire Community Stroke Project, published in 1983 and 1985, and the nomination of Charles Picton Warlow to be the first Professor of Medical Neurology at the University of Edinburgh in 1987, have since been followed by a flooding of important papers and prestigious prizes and nominations, giving him a relevant position as 'the' opinion leader in the field of clinical trials for prevention and treatment of stroke. Charles's participation as Principal Investigator in many major stroke trials, the publication of both Stroke: A Practical Guide to Management and the chapter on stroke in the 11th edition of the influential textbook Brain's Diseases of the Nervous System', in 2001, did certainly strengthen his leading cultural position.

In many of his papers he favours bold provocative titles, such as 'Stroke: killer clots and killer drugs' or 'Stop measuring blood pressure and plasma cholesterol'. Furthermore, in many of his texts he clearly indicates his likes and dislikes. Possibly, the Scottish attitude of avoiding over spending has led him to prefer aspirin to many other treatments for stroke prevention with a strong emphasis on the cost-to-benefit ratio, to restrain carotid surgery to pre-occlusive conditions and, alas, also to suggest that stroke patients do not benefit from hospital admission and expensive neuroimaging procedures; a negative attitude that has recently been revised thanks to the results from rtPA trials. But who knows what the final answer will be from our Edinburgh 'guru'?

In regards to these opinions, I have frequently had heated but friendly discussions with Charles, usually over a glass of good wine that he not only appreciates but about which he is as knowledgeable as I am.

The relevance of a thorough assessment of vascular physiopathology in hyperacute stroke patients for planning the right therapy with lower risks for disastrous adverse events has slightly modified Charles's position, as is evident in his more recent writings.

Charles Picton Warlow's early attraction towards water continues still, and recently in the more liquid form. Sailing has become his most dedicated hobby. He even tried to recruit me as a mate to sail around Australia a couple of years ago!

However often he may tell us that he is presently spending a lot of time '... sailing off the west coast of Scotland ..., I personally am convinced that with a mean of 10 full papers published yearly in the last 10 years, he still has ways to go before he is ready to compete with Luna Rossa for the Cup.
Having said that, I must tell you that he wrote to me saying that he would be preparing his lecture 'while ... sailing and gazing out at the horizon, glass in hand, on a gently rolling ocean with water dribbling down the back of my neck.' I am sure, therefore, that we will enjoy his presentation even more knowing its origin and that the European strokologists will forgive him for indulging in sailing in such a pleasant way.

I will finish the Laudatio with a curiosity. Perhaps some of you were asking why I insisted so much on the Picton component of Charles Warlow's name. First, because I am sure that very few knew why Charles's papers are always signed C.P., but let us suppose that we were assuming a possible 'Paul' or 'Peter' or 'Percival' or other more frequently utilized $P$ names.

So ... who is/was Picton? If you go to Google, you will find locations in New Zealand and in Ontario, a castle in Wales, a restaurant in Lecce (Italy, oh yes). You may find Picts, an early people inhabiting Scotland, possibly of pre-Celtic origin. But you will also find painting representing a military man, a soldier who was the second-incommand to Wellington. General Picton was famous for his courage, for his correct administration, but also for the rigour of his government, in particular for permitting the application of torture. He was fighting at Quatre Bras on June 16,1815, but he concealed his wound and retained command of his troops, and at Waterloo on June 18 he was shot through the head by a musket ball that spared his 'tube'. In fact, he was fighting with his civil dress, since he had not yet received his uniform from England. He is buried in the family vault in St. George, Hanover Square, and a public monument was erected to his memory in St. Paul's Cathedral.

Gian Luigi Lenzi 


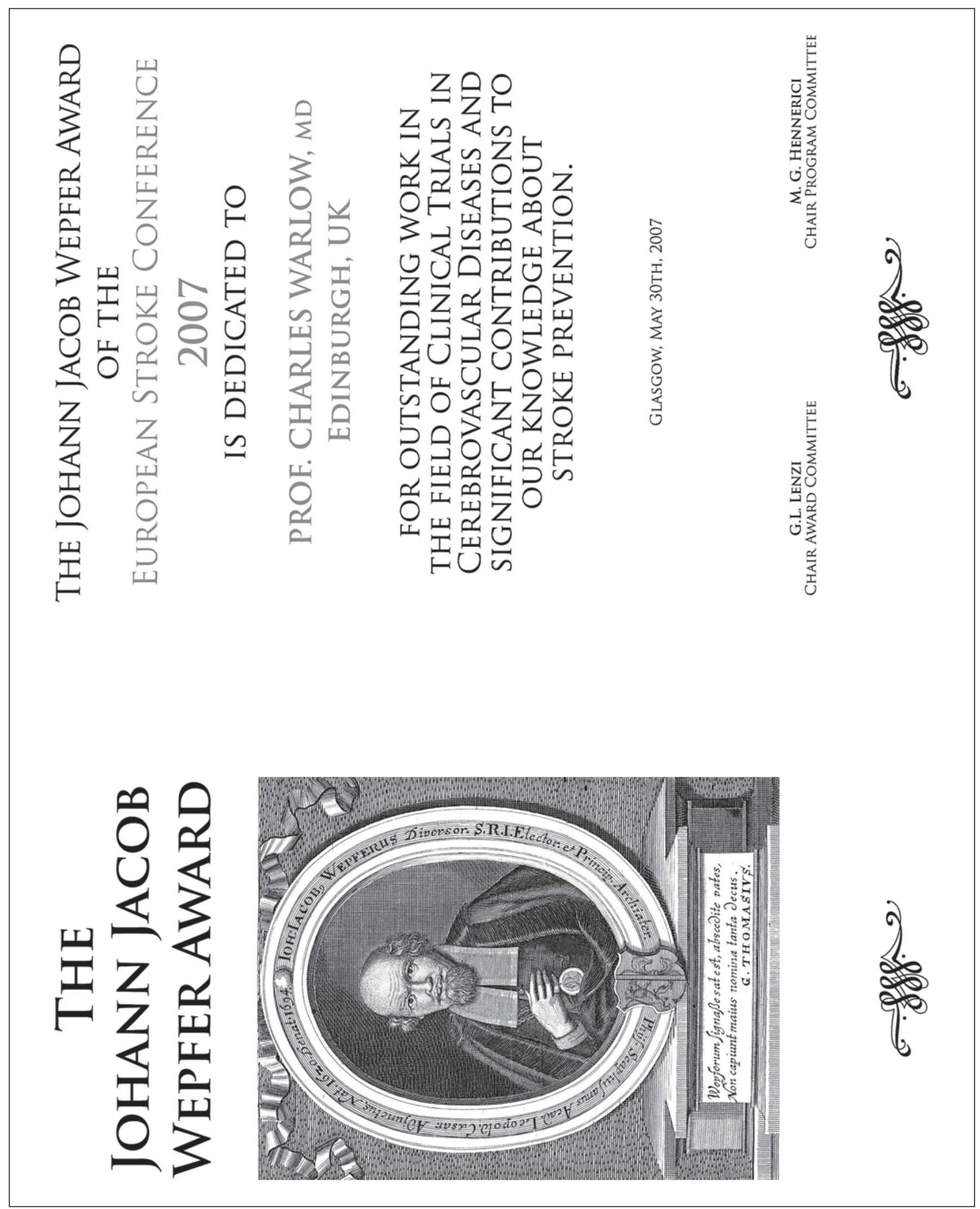

